\title{
The Perception of the British after the Fall of Fascism
}

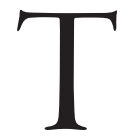

HE LANDING IN SICILY of a powerful Anglo-American invasion force in July 1943 convinced the Italian elites that a people with no remaining will or means to fight had to sue for peace. Mussolini had reached the same conclusions but had no plans nor energy left to change the course of events. On is July he met Hitler at Feltre, but obtained nothing. On the same day, Rome was bombed for the first time. ${ }^{1}$ On 25 July, Mussolini was arrested, and Badoglio, moving with the approval of the King, seized power and dissolved the Fascist Party. He promptly promised the Germans he would keep fighting. However, he was already in contact with the Allies to bring the country out of the war. How did the press react to these events? The bombing of Rome unleashed vicious anti-British and anti-American attacks, but the regime was by then next to collapse. ${ }^{2}$ After the fall of Mussolini, a sudden and clear change of tone can be seen in the Italian press. Rather than global criticism of Britain, the attacks now focused on the more anti-Axis characters of British politics, like Eden and Vansittart. ${ }^{3}$ Others criticised specific policies on the British side, like the fact that Italian prisoners working in the fields in the United Kingdom were forbidden to attend mass. ${ }^{4}$ The presence of American soldiers in Britain was also described as the source of endless problems. ${ }^{5}$ The article, which perhaps more than any other exemplifies this delicate period, appeared in Il Corriere on 2I of August. It started with a remarkable and, until recently, unimaginable admission: "In England and in the United States - countries to whom we recognise the merit of having allowed in the midst of the war, even in the hardest times, a note of critical freedom to newspapers - people began to analyse in a less self-congratulatory way the action of their military leaders towards Italy after the end of the Fascist regime." ${ }^{\prime 6}$ It continued by stating that there were reasonable people among the English, and the Americans, who understood that if the Italian people had cheered the fall of Fascism, that meant that it disapproved of the war Fascism had brought them in. However, the majority of the Anglo-Saxon public believed, the author wrote, that Badoglio, rather than just withdrawing 
Italy from the conflict, should simply hand over the country to the Allies for their march against Germany, and his delay in doing so was perceived as betrayal. The consequence was the mass bombing of Italian cities, aimed at breaking the morale of the despised Italian enemy. Some English newspapers even hoped that the Italian working class would rise and create anarchy in the country. An end - the author believed - of Italian civilisation in the name of an earlier end of the war. The article is full of ambivalence: unmitigated contempt for the Fascist authorities that had led the country into the war and for their journalistic sycophants; respect for the Allies mixed with hope of their magnanimity in victory; and nervous silence on Germany.

This ambivalence was the product of an anomalous political situation, which predictably collapsed soon enough. Once the armistice with the Allies was announced on 8 September 1943, the Germans swiftly proceeded in disarming most of the Italian army and occupied most of the country. Mussolini, freed by the Germans, was reinstated as head of the puppet regime known as the Italian Social Republic. The press adopted once again the most rabid anti-British tones. Besides underlining the great losses of the British Empire in the war, and generally parroting German war bulletins, the main argument on Britain was its voluntary downgrading from the rank of Great Power. One article published on Il Corriere in January 1944 is a clear example:

Even if it will manage to survive as an autonomous an empire. This is the result of an objective analysis of the postwar plans of the White House, as they have been outlined by the most important North-American characters [...] state, England will, after this war, cease to exist as a Great Power, as it is clear that, if Pluto Judaism pushed England to war, methodically preparing its unleashing, it was not only thinking of the great earnings through the furniture of cannons, airplanes, ships and other war means.?

Plutocratic Judaism had, according to the author, pushed the United States into the Great War in 1917 in order to weaken the rival power enough to grant a better economic position to dominate world markets. The plan failed, for Italy had defeated Austria-Hungary too soon, forcing an ending of the war before Britain was weakened enough to be forced to share its control of the markets with the United States. Forcing Britain into the Second World War, the lend-lease had the goal of reducing Britain to a beggar. Already Britain had sacrificed its influence in Latin America; its Dominions were now gravitating towards Washington rather than London. 'It only remains to be seen whether the remarkable British inheritance will end in the rapacious hands of the Pluto Judaism 
of beyond the Atlantic or if it will be made available for all the peoples, for the general well-being. ${ }^{8}$ Other articles insisted on the growing financial weight of the British debts with the Americans. ${ }^{9}$ Others focused on London's debt to its own Dominions..$^{10}$ Another article reported that the United States was legislating to completely exclude Britain from the markets of the Americas and to seize the British sources of raw matters as a payment for the help received during the conflict. ${ }^{11}$ Another article wrote that the seizing for a certain number of Italian ships to the Soviet government as part of the Italian armistice was additional proof of the downgrading of the British status. 'Once again,' the article stated, 'England had to subordinate its own interests to the ones of a tyrannical ally.'12 Mussolini himself unleashed violent anti-Anglo-Saxon tirades, and relished the idea that the Soviets would eventually get the upper hand over the Western powers. As James Burgwyn wrote, however, thanks 'to long-standing grievances that had built up over the years, Great Britain occupied the unenviable standing as Mussolini's principal bête-noir. ${ }^{13}$ The Duce did not just rehearse the usual anti-British tropes of egoism, double standards, snobbery and past and present vexations of Italian interests, but also stressed the fundamental incompatibility between the British mind-set and the socialist aspirations of his new Fascist republic. English mind-set, Mussolini told writer Carlo Silvestri in March 1945, was 'constitutionally antisocial and antisocialist,' and Mussolini kept identifying it with Italian decadent elites, hostile towards Fascist socialist experiments. ${ }^{14}$

\section{Public Sentiment in Occupied Italy}

Completely subservient to the Germans, mostly parroting German tropes, the anti-British propaganda in the Italian Social Republic is of limited interest. As we have seen, propaganda was also, by then, so discredited that its reception among the public was certainly limited. However, the war that was now ravaging the Italian Peninsula meant that the Allies were ever closer. How did Italians perceive them? An analysis of this public perception is deeply intertwined with the assessment the Italian people made of the Italian Social Republic and of the German occupiers. The reports of the Questori, who helplessly witnessed the erosion of the Fascist Republican state, provide an effective tool to investigate the subject, but the reader must be once again urged to consider that they are likely a more accurate depiction of people in urban areas and with at least some degree of education rather than rural dwellers. During 1943-1945, Italian peasants often helped and provided refuge to escaped Allied prisoners. Roger Absalom observed that an important reason for this was the widespread, almost 
instinctive distrust peasants had for 'the State,' and even a hope for a sort of palingenetic renovation of society. ${ }^{15}$ While this does not suggest any inherent sympathy for the Allied cause in particular, it does underline that Fascist propaganda had not shaped the image of the Allies in what still was, in Italy, an immense section of the population that somehow remained a world apart from the rest of the country. ${ }^{16}$

The first reports the Questori received after the creation of Mussolini's Republic were optimistic. One report from Padua stated that, by end of December 1943, most students had regularly shown up at the military districts 'to liberate our Italy from the ferocious enemies, who have slaughtered and tormented the harmless population and have destroyed the most beautiful and artistic Italian cities. ${ }^{17}$ Another positive report came from Florence in the same days. The political situation in Florence was good, but much work was required to reorganise the new regime and to face the 'rampant anglophile movements' and, especially, the Communists. ${ }^{18}$ A report from Lucca optimistically claimed that everyone in the region understood that the situation of Italy was very dire and nobody, with the exception of 'the few Judaic-freemasons serving the politics and the Anglo-masonic propaganda,' had faith in the much praised generosity of London and of the United Nations. ${ }^{19}$ Soon, however, the reports adopted a more pessimistic tone. In January 1944, the Questura of Ferrara ordered the confiscation of radios for who was recognised as a die-hard listener of foreign radios to 'limit the damage.' The report also stated that the masses thought there was no chance of final victory for the Tripartite and hence adopted an indifferent attitude. However, the 'barbaric' bombing of Ferrara had been met with deep, moved solidarity. ${ }^{20} \mathrm{~A}$ few days later, a report from Pisa mentioned numerous letters seized by the Questura mentioning worry for the bombings, for the development of military operations as well as overall pessimism and pacifism. This, despite the fact that the bombings had produced meaningful damage. ${ }^{21}$ The same was said of the people in Florence, who were dismayed by the landing at Anzio and the continuous bombings. ${ }^{22}$

The bombing campaign was a double-edged weapon for the Allies. In James Burgwyn's words, 'Indiscriminate American and British bombing triggered further Italian anger. Some considered them as outright bearers of wanton destruction rather than as liberators from Nazi oppression. ${ }^{23}$ The repeated bombings of Rome, one report stated, caused ever-growing indignation among the population of Milan, and many were 'finally changing their mind on the humanity and understanding of the Anglo-American "liberators" to the martyrised Italian people. ${ }^{24}$ Later, the "Vandalic destruction of the abbeys of Montecassino and 
Grottaferrata caused 'indignation especially among the clergy and the Catholic circles, which will have consequences on the behaviour of both, until now cold towards the war, Axis and Republican Fascism. ${ }^{25}$ Months later, a report from Padua stated that the population was calm and disciplined but in all social classes it was now widespread the hatred against the enemy 'for its barbaric air raids clearly carried out with no discrimination, against centres without military goals and against innocent people. ${ }^{26}$ However, it never lasted for long. A March report from Tuscany stated that not even the violent Anglo-American bombings against 'the City of Flowers managed to bring back to reality this people who reacts showing stronger aversion against the Germans' than against the 'liberators. ${ }^{27} \mathrm{~A}$ May report from Milan stated that no indignant reaction could be seen among the population against the 'liberators,' many even justifying the bombing as aimed at the central station of the city. The people were instead hostile against the Germans, accusing them of wanting to defend not Italy, but Germany on Italian soil, causing more destruction. Furthermore, 'there start to appear again in shops and businesses exercises of commercial propaganda in French while bookshops and pawn shops show many Italian-English dictionaries and manuals. ${ }^{28}$ In May 1944, the Questore of the Province of Imperia reported that 'the systematic, brutal massacre of our people and the destruction of our beautiful cities and works of art by the Anglo-American murderers of the air,' had not resurrected the 'love for the mutilated fatherland or for the martyrised population.' The Questore bitterly observed that the population of the Province, especially the people of San Remo and of the other tourist centres, were apathetic. Such behaviour could be explained, the Questore claimed, at least for the tourist places, with the fact that people living in the touristic centres were accustomed, in peacetime, to live alongside foreigners, and with the British in particular; furthermore, they were never of Fascist sentiment and never had any sympathy for the Germans. At the same time, as the people did not want to run any risk and wanted to preserve its earnings, Communist propaganda did not have much of an effect. ${ }^{29}$ One 'typical' example is the case of Forli. A 9 May 1944 report stated that the people of Forlì were tired of war, but 'foreign subversion' did not obtain its hoped effects. The political order remained normal, despite the propaganda from subversive parties and the enemy, especially through radio transmissions and the massive diffusion of booklets. ${ }^{30}$ On 19 May Forlì was bombed for the first time. The execration and hatred of the people against the authors of the 'massacre of so much innocent lives' were 'general and very intense' and roused a resurgence of patriotism even in those who were least favourable to the regime. The report stated that such a sentiment should be exploited by the propaganda. ${ }^{31}$ 
However, a new bombing on 9 June caused a depression in the population's morale, with many leaving the city for the countryside. ${ }^{32}$

Beyond the bombings, public sentiment was, to a certain degree, connected to the development of military operations. In February 1944, for example, one report stated that discipline in Florence grew again in February, thanks to the stabilisation of the front. ${ }^{33}$ Still, in May, people in Teramo reportedly hoped that the German troops and 'the bold Legionaries' would be able to defeat the Allied offensive at Cassino. ${ }^{34}$ However, morale was still overwhelmingly depressed. In March, while the front was still holding at Anzio, it was reported that in Florence the situation was already getting worse. The Fascist Party was not trusted, and the Communists found it useful to rebrand themselves as 'Nationalists,' defending Italian autonomy against both 'friends and enemies' their motto being 'Let us talk no more of Americans and English, we only want to save our Italy.' 35 A report from Pisa on the months of February and March described widespread pessimism about the outcome of the war. The youth was 'craven and focused on attempting to escape any duty.' Much importance was given to 'the hateful English propaganda,' which had managed to weaken the spirits and to 'break in many any hope for revanche and any trust in tomorrow. ${ }^{36}$ While the German resistance against the Anglo-Americans was exalted by a minority of the public opinion, the majority and part of the working class was indifferent. ${ }^{37}$ At the end of May, in Lucca, the masses were 'always hostile to Fascism,' considered responsible for the continuation of the war and were convinced of the final success of the Anglo-Saxons. That led to the widespread belief that it was important to not compromise oneself for the future. All the partisan bands, it was reported, showed Badoglian and pro-English principles, but the majority leaned toward Communism. ${ }^{38}$ The future relationship with the Allies, whose victory was by then considered unavoidable, worried members of the Republican administration as well. Riccardo Voltarelli, Questore di Forli, reported in July 1944 that the former Questore, Bertini, was waiting for the 'liberators' to reprise his role. His was the fault, Voltarelli claimed, of the bad relations between the Germans and the Questura, to the point that the latter was considered 'anglophile.' Voltarelli claimed that he was doing his best to repair the relations with the Germans. ${ }^{39}$ The population of Forlì was as sceptical, certain as Bertini on the possibility of an Axis victory, and recognised the overwhelming superiority of the Allies. ${ }^{40}$

The Italian people under German and Republican control, manifestly, were certain of the eventual Allied victory and did not trust or particularly support the Fascist regime. At the same time, while the bombing campaigns would often fuel anti-Allied sentiments at first, these feelings would soon be replaced 
by dismay and apathy, or by hostility towards the Germans and the Republicans themselves. How then did the population feel about the approaching Allied forces? One August 1944 document from the Questore of Imperia reported that The German defeats on the Western front caused 'real worry in the soul of the healthy section of the population of this province, with no distinction of party affiliation, for what could be the doom awaiting the region if the Anglo-Americans were to occupy Liguria.' These days, the Questore continued, good-faith people heard of the real treatment reserved to the parts of Italy invaded by the Anglo-Americans, which greatly differed from the one described by enemy propaganda. ${ }^{41}$ A similar notion is displayed by a November 1944 report from Verona. The terror bombings on the city had 'forced many back to reality and to reflection,' and now only a few still longed for the Anglo-Americans, because the belief was spreading that with the arrival of the enemy everything would collapse. ${ }^{42}$

By March 1945, such traces of caution were gone. One report from la Spezia stated that the population was hostile to the Fascist government and to the Germans because of the 'heavy food shortages and the effective enemy propaganda, the mirage of a calm existence, which the subversives prospect in wishing for the near arrival of the English [...] all these factors influence the masses, which now, almost completely,' were resigned to the fact that the war was lost and that the 'much praised "liberation" ' was at hand. ${ }^{43}$ One report from Parma stated that the population, used to obey the strongest, gladly submitted to the partisan bands, which were moved by the English. ${ }^{44}$

\section{Popular Sentiment in Liberated Italy}

As we have seen, the previous reports did often use the term 'English' to describe the Allies in general. However they did not particularly focus on British politics or attitudes in particular, and appeared to perceive the Allies as a monolithic entity. Given their experience of the diverse realities of Allied occupation, an analysis of the perception of the British in the regions of Italy that were liberated by the Allies is more useful to the scope of this project. As George Talbot wrote, 'Lepre has argued that the historian may then imagine the surprise of the censors and informers at the end of the war in 1945 when they heard accounts of friendship and regard for the British and Americans among the Italian population generally. In fact, there was little or no trace of such sentiments in the letters they censored or the reports [that] they filed. Indeed, up until July 1943 the British and the Americans were referred to, in terms 
of open hostility, as the enemies raining bombs down on Italy. ${ }^{45}$ The analysis in chapter 5 confirms this view, but it stresses as well that the two main Allied powers were not regarded in the same light. ${ }^{46}$ This was one reason why Italians' memories of Allied occupation tended to concentrate on US soldiers especially, whose spending power and consumption were considerably higher than British troops,' even though British officials and soldiers had a bigger role in the Allied occupation and administration of liberated Italy.

The Italian government under Badoglio and the King survived the catastrophe of the armistice in September 1943. The inglorious flight of the King to Brindisi left, what was now known as the 'Kingdom of the South,' in control only of a very small part of the country. As the Anglo-American armies (as well as some Italian units) fought their way north against the Germans and the Fascists, more regions were placed under Italian administration. The Allies had no interest in occupying every inch of Italian land they liberated from the Germans, and yet Churchill, for one, was worried that if Badoglio proved too weak to control the population, they would be forced to do so. ${ }^{47}$ Hence, a remarkable effort was made to check the pulse of the population's sentiments. The most useful tool to analyse the perception of the Allies (and, in particular, of the British) in the liberated regions are the reports on the censorship drafted by the Kingdom of the South's Intelligence. As Nicola Della Volpe wrote, 'in [1943-1945] propaganda and censorship thoroughly measured the sentiments of the military and of the country, the economic and political situation, and the dangerous moral reverberation the war had on social issues. ${ }^{3} 8$ These were based on statistical analysis of daily reports coming from the occupied provinces, and hence are relatively trustworthy. ${ }^{49}$ Integrated by the reports by the Questure, these documents help reconstruct the mosaic of the perception of the British in liberated Italy.

Traditional assessment of Allied occupation of Southern Italy has been negative. ${ }^{50}$ Della Volpe wrote that, just a few weeks after the liberation, any enthusiasm for the Allies had already vanished. Already in October, Della Volpe wrote, all the delusions born out of Allied propaganda had been erased by the indifference and lack of interest of the Allied administration, the AMGOT (Allied Military Government of Occupied Territories). The catastrophic conditions of the population, the unrest, the protests and decay were 'invariably repeated' as the Allies advanced towards the North. ${ }^{51}$ De Volpe's analysis seems to rely on two reports written by Italian officers. Written in December 1943, one relation from Lieutenant Colonel Gaetani described a catastrophic situation in Sicily. The Allies, he wrote, removed capable men who were only guilty of having 'Fascist origins,' they jeopardised the institutions without rebuilding anything in 
their stead, and what remained of the Italian authorities had nothing to work with. Unrest was widespread, the Mafia was awakening, and many Sicilians remarked that, after having been betrayed by Fascists and Germans, they were now abandoned by the Allies too.' Another report mentioned by Della Volpe was written by General Mario Arisio. The general wrote that the Allied administration of the region was 'incompetent and aboulic,' as well as uncaring of the Italian bureaucracy. Arisio had been particularly upset by the arrest of Fascists as a consequence of 'extremist elements' informing the Allies. All in all, Arisio concluded, the impression was that the AMGOT officers did not enjoy the trust of the people, for they relied on the less healthy elements of society, who 'wanted to fish in murky waters,' and that many of them were corrupt. ${ }^{52}$ How accurate is this description? Gaetani and Arisio clearly wrote with an anti-Allied bias. Gaetani was incensed by the purging of Fascists, and Arisio, whose report was written to chief of staff of the Regio Esercito (and former zealous Fascist as well as war criminal) General Mario Roatta, had been fighting against the British in Calabria a few weeks before. Not taking the armistice well, he had cooperated with the Germans and had 'freely turned vehicles, supplies, and facilities over to the Germans and voluntarily gave German troops the good coastal positions they occupied. ${ }^{53}$ While a complete analysis of the perception of Allied occupation and administration is beyond the scope of this work, the following pages will underline a more nuanced reality, which belongs in the middle between the triumphal myths on an Italian people ever-grateful to the Anglo-Americans and the grim, and essentially exaggerated words of Gaetani and Arisio.

The conditions of the recently liberated south were indeed dire. According to AMGOT'S internal sources, Naples was the worst administered city in the western world, and the conditions in Southern Italy and Sicily required the shipment of supplies to prevent riots and plundering with the potential to threaten Allied advance. The food rationing was another grave reason of discontent. According to AMGOT reports, it was not the excessive purge of Fascist elements but the maintaining of many Fascists in key positions, especially close to the food supplies, that offended many Italians. ${ }^{54}$ However, the reports of the Questori and the reports on the censorship depict a more nuanced situation, where malcontent is tempered by an overall good opinion of 'the Allies' although with the British being consistently seen more negatively than the Americans. These findings are consistent with new developments in historiography, which underlined how the Allies were not completely at fault for the hardships endured by the Italian population..$^{55}$ In April 1944, as the battle raged at Anzio, a report stated that the civilians' opinion was favourable to the Allies and an ever-increasing sympathy 
for the Americans. ${ }^{56}$ The victorious Allied push in central Italy during May and June galvanised the population. A July report described how, due to the admiration for the Allied successes, hostility towards the Allies was less common than previously, although unrest related to the uncompensated damages lingered. ${ }^{57}$ In August the Allied administration in the $\mathrm{V}$ region (Abruzzi and Marche) reported that the population was very favourable to the Allies and it appreciated the problem that AMGOT faced in the new provinces. ${ }^{58}$ One report on the public opinion in the Province of Benevento stated that in September 1944 'it was now believed that the Allies do not want to make the Italians feel a war they do not feel any longer, and into which they were dragged by a regime that denied any free expression of thought. ${ }^{59}$ Not unlike what had happened in Southern Italy, however, a certain degree of malcontent followed, due to the hardships endured by the liberated population. After the occupation of Rome, for example, the Allied administration reported that the people of Rome were disappointed in the Allies, for they had allowed the people to get restless and undernourished, and that such feelings were exploited by the Communists, who repeated that the Allies had not fulfilled their promises. ${ }^{60}$ Things were worse in the south. In the same month, incidents were recorded between British military personnel and the population in Apulia. English sailors harassed a girl and Italian sailors intervened, with the consequence of one Italian being killed; another incident occurred between English soldiers and a carabiniere. ${ }^{61}$ The incidents continued in the following months. In November, two English soldiers stopped a farmer, slapped him, and robbed him of his bike; at Fasano four drunk English soldiers robbed another farmer, other English soldiers robbed a haberdashery at San Vito dei Normanni, and one drunk and aggressive British soldier was wounded by a gunshot at Catiano. ${ }^{62}$ Churchill's speech at the Commons (in September) had produced a very good impression as it had been considered a step towards a real alliance. ${ }^{63}$ However, these incidents proved how the relationship with the British remained tense. Things were better with the Americans, however. In October, it was reported that the people of the Province of Matera showed a clear preference for the Americans and the Polish, who were seen as 'kinder and generous.' Interestingly, the report compared this positive sentiment with the 'coldness towards the Anglo-Saxons' - here clearly including the British Dominions but not the Americans. ${ }^{64}$ Things were not different elsewhere. In October 1944 the censorship report stated that the opinion of the Allies remained 'good,' but the disappointment and criticism for the living conditions in the country were growing. ${ }^{65}$ One censored letter from Palermo however stated that 'our hope is America, only she can eventually provide us with what we need. ${ }^{66}$ In December 
1944, the bad blood with the British led to a major incident in Bitonto, near Bari. After a series of house perquisitions decided by the local Allied command, the population exploded in a violent demonstration against the British colonel in charge of the garrison, asking for the liberation of the twelve men arrested for having been found in possession of Allied goods. One British soldier, trying to intimidate the crowd with his rifle, was overwhelmed and beaten. The British colonel shot many gunshots against the crowd, killing two and wounding six. Other British soldiers dispersed the demonstrators. Such clashes were not new. As C. Cappellano and A. Gionfrida wrote, however, they became more dangerous in early 1945 because by then they started involving whole groups of Italian soldiers armed with automatic weapons and hand grenades. ${ }^{67}$ It is interesting to underline that the episodes mentioned by Cappellano and Gionfrida were all between Italian soldiers and British or Commonwealth forces. To make things worse, Eden had recently harshly criticised the Italian nation. ${ }^{68}$ These sentiments festered and in December it was reported that the civilian opinion, while still generally favourable to the Anglo-Americans, was irked by the prolonged difficulties. The popular expressions of sympathy for the Allies were meaningfully less common than before. One letter, for example, stated that 'Americans and English are tidy and clean in their clothes, but they have the horrendous vice of drinking too much alcohol.' As ever, it was Britain that was particularly targeted. One letter stated that 'there is a stubborn and growing irritation especially in the regard of England, because of its opposition to the dispatch of the promised help, especially in the alimentary field.' Another claimed that 'we waited with so much trust and longing the Allies ... and for the first days we believed and loved them ... America was moved to compassion by the miserable state of Italy, but the English ambassador, in the name ... of generous England, was against ... did not they say that they wanted to wage war against Fascism rather than the Italian people?' There was one exception, saying 'Englishmen are good people, they do not harm anybody. ${ }^{69}$ Things did not quickly improve. Other incidents followed in December and January 1945, with Italian parachutists shouting 'viva il Duce' at English soldiers, with aggressive intentions, and the same happening in the circle of English officers. A January report on the public opinion in Benevento explained that 'The obvious influence of England in our domestic politics caused bitter comments on the freedom allowed to our political tendencies [... The incidents in Greece and Churchill's speech on the Polish issue, generally considered as coldly calculating, made large impressions. ${ }^{70}$ In February 1945, the general opinion of the military was, once again, overall favourable to the Allies. Italian soldiers reported that their contribution to the 
war was being appreciated, even by the British. The unfavourable comments, it was reported, were not very common and were directed against Britain. One soldier of unspecified rank wrote that

among us there is widespread animosity towards the English, who keep proving themselves inferior to their task, and ignore our needs, moral as well. Eden does not speak but to vomit venom on the Italian people. Churchill often has harsh words for us. "We do not need Italy," Mr. Churchill forgets that Italians have a dignity that was forged by centuries of sacrifice ... Casablanca was quickly forgotten by the old anti-Bolshevik Tory. Let us hope that the messianic Roosevelt does not do the same ... or Italy will not have [any] other choice but to turn to the starosta' the quiet neo tzar, or little father, Stalin who, with his imperialist social conservatism, is working with great diplomacy. ${ }^{71}$

The report also mentioned the anger for how the British dealt with the Italian units under their control, and irritation for the haughtiness and contempt of 'some English element' towards the Italian soldiers. One officer wrote that 'I just arrived at the new unit, which is under English control ... I understood that life is quite hard, having to endure their often-unjustified checks and a humiliating and distressing treatment.' One soldier wrote that 'I am in a unit tasked to work with the English $8^{\text {th }}$ Army. Of the two, I would rather be alongside the Americans for ... they behave differently. Americans in Italy always behaved as friends, no arrogance or haughtiness, while the English hate us, they mistreat us, acting as winners, and I hate these things . . . ${ }^{72}$ In March 1945 the sentiment was positive among the military, the few negative ones were annoyed for the lacked recognition of Italian help. Very different was the civilian situation: 'the lack of trust and scepticism towards the Allies, because of their ambiguous policy concerning Italy and concerning the integrity of Italian borders lingers' and there was unrest due to the lacked repatriation of the prisoners. However, once again, the criticism against the Allies was disproportionally directed at the British. One letter said that 'to keep prisoners still is unfair ... we are not enemies of England anymore, but co-belligerents [. . .] why do they keep the prisoners then?' Other letters praised the Americans (described as very charitable, valiant, friends of all) and criticised the British who, in Naples and in all the cities where there were many of them, 'always got drunk and [bothered] the population. ${ }^{73}$ A report from Avellino mentioned that the presence of Allied troops, welcomed with so much enthusiasm in October 1943, caused in the citizenship one ill-devised malcontent for the requisitions and other things. No 
acts of hostility had been carried out because everyone knew the unavoidable consequences of the defeat and needed the food help from the UNO. In the end, they longingly waited for the not far victorious conclusion of the conflict and the liberation from all foreigners. ${ }^{74} \mathrm{~A}$ February report from Avellino stated that many circumstances had negatively influenced the sentiment of the population towards the Allies, especially the British; the initial enthusiasm, long gone, has been replaced by an increasing sentiment of lack of trust and almost rancour. The unfulfilled promise of material and financial help, long the object of press propaganda; the uncertainty on the details of the armistice; the declarations at the Commons of Eden; and Churchill, openly and willingly hostile towards Italy, had disappointed both the expectations of a material improvement and the hope of a recognition of the material and political rights of Italy. ${ }^{75}$ Yet, as we have seen, the main source of antagonism between the liberators and the Italian people was the war itself, and the difficulties it brought about. Unsurprisingly, then, the end of the war in Italy in April 1945 led to a great wave of pro-Allied enthusiasm. Reports drafted in April show that the military considered the Allies cordially, although there were rare episodes of unrest and hostility, especially for the lack of recognition of the Italian contribution. Everyone, however, wished to end, once and for all, the arrogance, cruelty and mania of destruction of the Germans. The real change was among the civilians, where sympathy and gratitude were prevalent, especially from the territories that had been recently liberated. Again, sympathy was skewed towards the Americans: one letter from Cagliari stated that 'Americans are esteemed here ... the English are well liked too, but not as much as the former. ${ }^{76}$ The reports in the months after the end of the war showed a clear improving trend in the relations with the Allies. For example, in June 45 the Prefettura in Cagliari reported that the population's behaviour towards the

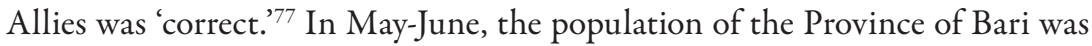
reported to be hospitable to the Allied forces from April to May and August. ${ }^{78}$ In April-August the same friendly attitude towards the Allies was reported for the Province of Grosseto. ${ }^{79}$

What conclusions can be drawn from an analysis of these reports? The underlying sympathy for the Americans was rooted in the positive experiences shared by many Italian immigrants returning from the United States, many of whom had experienced America as a land of, in the words of Roger Absalom, 'abundance, generosity and loyal friendship. ${ }^{90}$ The preference for the Americans over the British was, however, also consistent with the general dislike for the latter, analysed in the previous chapters. Mussolini's imperial ambitions had been shattered, but a widespread rancour against the British lingered. As Burgwyn 
argued, 'Italians almost universally shared Mussolini's resentment of some unforgettable examples of British snobbery, which stemmed from a belief in certain upper class circles that Italy was an excellent vacation haunt for those who would take pleasure in the lavish attention of born-to-serve errand boys, hotel owners and restaurant chefs. ${ }^{\text {'1 }}$ It was, however, not just a matter of national character. The British were also seen, especially in the more educated sections of the population, as the power attempting to damage Italy as much as it could, even when the country was on its knees. The Americans shared that perception. James Clement Dunn, American diplomat and future ambassador in Italy, believed that the vengeful British had sabotaged the Italian efforts to establish themselves as an effective cobelligerent, even though they had the American support. ${ }^{82}$ Historiography demonstrated that the difference between the American and the British point of view was, in reality, more about optics than facts, with both the Allied powers trying to limit the military contribution of the Italian forces. ${ }^{83}$ Regardless, the notion stuck. Furthermore, frictions developed as the British tried to shape the political future of the country. While the Americans favoured a Republican Italy, the British hoped that the monarchy could survive and fought as hard as they could to make it so. ${ }^{84}$

Churchill's support for the Monarchical institution meant he harshly opposed not just the Italian Communists and republicans, but the moderate, liberal adversaries of King Victor Emmanuel III and the Badoglio Government, like the anti-Fascist Count Carlo Sforza, returned from exile. Even after Badoglio was gone, the hostility lingered. By 1944, Sforza was high commissioner for epuration of the Fascists and leader of the radically anti-Fascist politics of the Central Committee for National Liberation. ${ }^{85}$ The conservative approach of London led to Sforza's attempts to become foreign minister to fail twice, in 1943 and in $1944 .{ }^{86}$ This incident was commented on negatively by the prestigious liberal, socialist magazine La Nuova Europa, in an article entitled English Policy and Italy. The article summed up the details of the falling out between Sforza and Eden and concluded the following:

The logical conclusion would be that the anti-Fascist struggle is, in the eyes of the English government, a flaw rather than a merit: it is the cause of disdain and even (in the case of Sforza against Victor Emmanuel) as a clear guilt. Italy's position is seen in London, at this time, completely outside the 'Fascism-anti-Fascism' and 'totalitarianism-democracy' antitheses. Italy is simply considered as a 'operation base': that is, this war (at least concerning our country) has a merely military and political-national character. The 
First World War begun as just any [qualunque in the text] war, ended as a war of ideas: the second, begun as a war of ideas, would then end as just any war. This would be the logical conclusion. Perhaps, however, the English would tell us we are wrong in being logical. We hope that is so. ${ }^{87}$

Anti-British sentiment had never been a Fascist prerogative. The end of the regime paved the way for new sources of hostility.

One important example of attrition between the new Italy and Britain was the case of General Bellomo, who was unfairly accused by the British of being a war criminal and executed in September 1945. The trial triggered a negative public response in Italy, worrying the British authorities. ${ }^{88}$ However, the context was changing. British influence over Italy was weakening, as Effie Pedaliu has pointed out, by January 1946, when the Allied occupation regime ended, Italy was no longer on its knees and Britain was not as powerful as it once had been. ${ }^{89}$ The two nations would need to learn to set aside the wounds of the past and interact as sovereign nations with a close relationship. The British labour government proved, if in a much slower fashion than many Italians had hoped for, that such was its intention. The punitive attitude of Churchill and Eden was replaced by a constructive policy aimed at turning Italy into a stable country and reliable partner. ${ }^{90}$ 